\title{
Porous poly(urethane urea) microparticles for immobilization of maltogenic $\alpha$ amylase from Bacillus stearothermophilus
}

\author{
Antanas Strakšys ${ }^{1^{*}}$, \\ Tatjana Kochané⿱2 , \\ Sandra Mačiulytė ${ }^{1}$, \\ Saulutè Budrien $\dot{e}^{2}$ \\ ${ }^{1}$ Center for Physical Sciences \\ and Technology (FTMC), \\ 3 Saulètekio Avenue, \\ 10257 Vilnius, Lithuania \\ ${ }^{2}$ Faculty of Chemistry and Geoscience, \\ Vilnius University, \\ 24 NaugardukoStreet, \\ 03225 Vilnius, Lithuania
}

\begin{abstract}
Maltogenic a amylase from Bacillus stearothermophilus (BsMa) was immobilized by covalent attachment and physical adsorption onto porous poly(urethane urea) (PUU) microparticles obtained from poly(vinyl alcohol) (PVA) and 4,4'-methylenebis (cyclohexyl diisocyanate) $\left(\mathrm{H}_{12} \mathrm{DI}\right)$ by onepot synthesis. The influence of PUU synthesis parameters such as PVA and $\mathrm{H}_{12}$ DI molar ratio, synthesis time and temperature on porosity, surface area, structure of microparticles and catalytic activity and stability of immobilized BsMa was investigated. The highest efficiency of the immobilization of BsMa onto the PUU carrier was $97 \%$ and the highest residual stability of the immobilized enzyme reached $95 \%$ after 28 days of storage at $4^{\circ} \mathrm{C}$. The optimal activity temperature of immobilized BsMa was at $80^{\circ} \mathrm{C}$ and it was higher than that of native enzyme. Effects of ionic strength and repetitive batch processing cycles on the activity of immobilized BsMa were also studied. Immobilization of BsMa onto PUU carriers has a great potential for biotechnology and food industries.
\end{abstract}

Keywords: poly(urethane urea) microparticles, porous carrier, amylase immobilization, covalent binding, physical adsorption

\section{INTRODUCTION}

Immobilization of an enzyme is one of the main factors, determining the success of its utilization. Enzyme immobilization methods typically include adsorption or covalent linking to insoluble organic compounds, inorganic materials, or organometallic frameworks, entrapment in a polymeric matrix, encapsulation, crosslinking with a bifunctional reagent, diffusion into the pores of materials and other mechanisms [1-4]. Out of many methods of enzyme immobilization onto various supports, just a small part relates to utilization of the porous materials, especially polymeric particles. Generally, silica in a form

\footnotetext{
* Corresponding author. Email: antanas.straksys@ftmc.lt
}

of porous particles is used as an inorganic support for enzyme immobilization [5-11]. Porous inorganic particles such as montmorillonite [12], mica [13], zeolites like ZSMI-5 [14], activated carbon [15] and porous glass-ceramic [16] have been used for enzyme immobilization.

Polymers have been used as carriers for enzyme immobilization, especially porous particles which have functional groups. Miletic et al. have synthesized porous polymer particles from glycidyl methacrylate (GMA) and ethylene glycol dimethacrylate (EGDMA), and then lipase from Candida antarctica was immobilized through free epoxy groups by covalent attachment [17]. Rana et al. have treated chitosan microspheres with GA and $\alpha$ amylase was immobilized by covalent attachment [18]. A very interesting approach to enzyme immobilization 
onto mesoporous polymethacrylate polymer particles has been used by Lage et al. [19]. However, only a few reports are available about the use of PU particles for enzyme immobilization [20-22] and even fewer about porous PU microparticles [23-25]. Wang and Ruckenstein have synthesized polyurethane microparticles from polymethylene bis(phenylisocyanate) and polypropylene glycol, producing the pores by adding calcium carbonate which was washed out after synthesis. Lipase from Candida rugosa was immobilized on these porous PU particles by physical adsorption and, additionally, it was fixed with GA [23]. The microporous carrier was synthesized from $\beta$-cyclodextrin and diisocyanate (4.4'-methylenebis(cyclohexyl isocyanate) $\left(\mathrm{H}_{12} \mathrm{DI}\right)$ or 4,4'-methylenebis(phenyl isocyanate) and it was used for lipase immobilization by physical adsorption with the efficiency of immobilization (EI) reaching 89\% [24]. Lipase from Candida antarctica was immobilized onto porous PUU nanoparticles from isophorone diisocyanate and polycaprolactone diol, which were synthesized by a miniemulsion method and the enzyme was encapsulated via a synthesis procedure [25].

Our research group has explored the immobilization route of BsMa onto PU and PUU microparticles by covalent attachment when enzyme functional groups reacted with free isocyanate groups of the carrier [26-28]. Except our own research, we are not aware of other studies of BsMa immobilization onto porous PUU microparticles, which report properties of the porosity of carrier [29]. The use of porous PUU microparticles may improve the efficiency of enzyme immobilization because synthesized particles provide a large surface area, a suitable pore size for the entrance of the enzyme and free isocyanate groups for covalent attachment [29].

In this paper, one-pot synthesis of porous PUU microparticles from PVA and 4,4'-methylenebis(cyclohexyl isocyanate) $\left(\mathrm{H}_{12} \mathrm{DI}\right)$ is presented along with a study of the immobilization of maltogenic a-amylase from Bacillus stearothermophilus on these porous microparticles. The effects of different synthesis conditions of PUU microparticles, such as initial molar ratio of PVA and $\mathrm{H}_{12} \mathrm{DI}$, synthesis time and temperature, on the porosity of the carrier and the enzymatic activity and stability of the immobilized enzyme were evaluated. Reusability, ionic strength effects and the optimal temperature of activity of the immobilized enzyme were also investigated. The results reported in this article show that PUU microparticles may be suitable as carriers for the immobilization of BsMa and they have the potential to be used in food and biotechnological areas.

\section{MATERIALS AND METHODS}

\section{Materials}

4.4'-methylenebis (cyclohexyldiisocyanate) $\left(\mathrm{H}_{12} \mathrm{DI}\right)$ and dimethyl sulfoxide (DMSO) were purchased from Sigma-Aldrich, France. Acetone was purchased from Reachem Slovakia, Slovakia. Diethyl ether was purchased from LACH-NER, Czech Republic. Sodium chloride was purchased from Aldrich, Germany. Starch from potato was purchased from Beroxfood, Germany. Poly(vinyl alcohol) (PVA), $M_{w} 100000$ (degree of hydrolisation $86-89 \mathrm{~mol} \%$, viscosity ( $4 \%$ in water, $20^{\circ} \mathrm{C}$ ) is $34-$ $45 \mathrm{mPa} \cdot \mathrm{s})$, was purchased from Fluka, Switzerland. PVA was dried under vacuum at $60^{\circ} \mathrm{C}$ for $24 \mathrm{~h}$ and kept in a desiccator. All other reagents were used as received.

Maltogenic $\alpha$-amylase (EC 3.2.1.133) (4000 U/ $\mathrm{ml}$ ) from Bacillus stearothermophilus (BsMa) and a-amylase (EC 3.2.1.1) $(25000 \mathrm{U} / \mathrm{ml})$ from Bacillus subtilis were obtained from Novozymes, Denmark. Commercial enzymes preparations were used as purchased without additional purification.

\section{Synthesis of PUU microparticles}

Poly(urethane urea) (PUU) microparticles were prepared according to our previous reported method [29] with the exception that another diisocyanate $\mathrm{H}_{12} \mathrm{DI}$ was used and the solvent DMSO/water ratio was changed by introducing more water. Briefly, PVA was dissolved in a dimethyl sulfoxide/ water $(98 / 2$ vol\%) solution. The initial concentration of PVA was $0.06 \mathrm{M}$ (mole of repeating units of PVA). The solution was loaded into a three-necked flask containing a magnetic stirrer and a reflux condenser with an attached drying tube and an argon gas inlet. $\mathrm{H}_{12} \mathrm{DI}$ was added and the reaction was carried out at $60-130^{\circ} \mathrm{C}$ temperature for $60-180 \mathrm{~min}$. The initial molar ratio of PVA and $\mathrm{H}_{12}$ DI was varied from 1:2.0 to 1:6.0. The obtained PUU microparticles were precipitated into an acetone/diethyl ether mixture and were immediately used for the immobilization of BsMa. 


\section{Characterization of PUU microparticles}

The quantity of isocyanate groups of PUU microparticles was determined immediately after synthesis by a chemical method [30]. FT-IR analysis was performed by using a Perkin Elmer FRONTIER FT-IR spectrometer. The size and morphology of microparticles were assessed by using a scanning electron microscope Hitachi SU 70 and an optical microscope Olympus BX 51. The surface area and porosity of the PUU microparticles were determined by using a Micromeritics Tristar II instrument. The samples were degassed at $140^{\circ} \mathrm{C}$ for $2 \mathrm{~h}$ prior to the experiments to eliminate any volatile compounds from the lyophilized PUU microparticles. The surface area was evaluated by using the Brunauer-Emmett-Teller (BET) model from the isotherm analysis in the relative pressure range of $0.05-0.22$. The total pore volume was determined from the adsorption isotherm at the relative pressure of 0.98 . The pore size distributions were derived from the desorption branch by using the Barret-Joyner-Halenda (BJH) model.

\section{Methods on enzymatic assay of immobilized BsMa onto porous PUU microparticles}

The method of preparation of a liquefied starch solution was described in our previous articles [27, 29].

The immobilization of BsMa onto PUU microparticles and the determination of catalytic activity of the native and immobilized BsMa onto the carrier was described in the previous article [29]. In this work, the amount of reducing sugars was determined spectrophotometrically by the neocuproine method [31]. The protein content in the native enzyme solution or left in the solution after immobilization was assayed by the bicinchinonic acid method (BCA kit) [32]. The efficiency of immobilization (EI) was defined as the specific activity of the immobilized BsMa in percentage from the activity of the native enzyme used for the immobilization:

$$
E I(\%)=\frac{\text { activity of immobilized enzyme }}{\text { activity of native enzyme }} \cdot 100 .
$$

The yield of immobilization by protein (YP) was defined as the protein quantity of the immobilized enzyme in percentage from the quantity of protein of the native enzyme used for the immobilization:

$$
Y P(\%)=\frac{\text { Protein quantity of immobilized enzyme }}{\text { Protein quantity of native enzyme }} \cdot 100 .
$$

The storage stability and evaluation of the operation stability (7 cycles) of the immobilized BsMa in a batch type reactor was described in the previous article [29].

\section{Effect of sodium chloride concentration on} the activity of native and immobilized BsMa To evaluate the effect of sodium chloride concentration on the activity of immobilized BsMa, PUU microparticles with the immobilized enzyme $(0.1 \mathrm{~g})$ were incubated in $10 \mathrm{ml}$ of the $0.1 \mathrm{M}$ sodium citrate buffer solution $(\mathrm{pH}=5.0)$ which contained $0.01-0.10 \mathrm{M} \mathrm{NaCl}$ at $40^{\circ} \mathrm{C}$ for $20 \mathrm{~min}$. In the case of native BsMa, $1 \mathrm{ml}$ of the BsMa solution diluted 160 times was used. After the incubation, the immobilized BsMa was filtered and washed several times with the $0.1 \mathrm{M}$ sodium citrate buffer $(\mathrm{pH}=5.0)$. The activity of immobilized BsMa after the treatment with $\mathrm{NaCl}$ was carried out as described in the Section 'Effect of temperature on the enzymatic activity of native and immobilized BsMa'. The initial activity of the immobilized enzyme without the addition of $\mathrm{NaCl}$ was expressed as $100 \%$. Others were expressed as the relative activity to the initial activity of the immobilized enzyme.

Four separate measurements of the native and immobilized BsMa were performed to check the reproducibility of the data.

\section{Effect of temperature on the enzymatic activity of native and immobilized BsMa}

The effect of temperature on the activity of immobilized BsMa onto the carrier $(0.1 \mathrm{~g})$ was determined by carrying out the starch hydrolysis reaction at various temperatures ranging from 20 to $80^{\circ} \mathrm{C}$ for $20 \mathrm{~min}$. In the case of native BsMa, $1 \mathrm{ml}$ of the BsMa solution diluted 160 times was used. The temperature showing the maximum activity was taken as optimal for the enzyme. The relative activity (\%) at each temperature was calculated by considering the enzyme activity at the optimal temperature as $100 \%$.

Four separate measurements of the native and immobilized BsMa were performed to check the reproducibility of the data. In all statistical analysis, only $p$ value $<0.05$ was considered statistically significant. 


\section{RESULTS AND DISCUSSION}

\section{Synthesis and characterization of porous PUU microparticles}

New enzyme carriers - porous PUU microparticles - were synthesized from PVA and $\mathrm{H}_{12} \mathrm{DI}$ in a $\mathrm{DMSO} / \mathrm{H}_{2} \mathrm{O}$ solution (98/2 vol.\%). The synthesis was carried out according to the methodology described in our previous articles with exception of the amount of water in the reaction mixture [28, 29]. Water has been added to the reaction medium for two reasons: first, it was used as a foamer; second, it helps to form urea linkages in PUU. The water molecules react with the isocyanate groups, resulting in carbon dioxide acting as foamer and amino groups. The amino groups react with other isocyanate groups to form urea bonds. The results of the synthesis of porous PUU microparticles are shown in Table 1 and Figs 1 and 2 . The size and morphology of PUU microparticles were investigated by scanning electron micros- copy. The yield, isocyanate content and porosity properties of PUU microparticles are highly dependent on synthesis conditions such as time and temperature. Changing the initial molar ratio of PVA and $\mathrm{H}_{12}$ DI from $1: 2$ to $1: 6$, resulted in an increased yield of the PUU microparticles from 38 to $55 \%$. The quantity of NCO-groups, the formation of open pores and the surface area were increased with increasing the amount of $\mathrm{H}_{12} \mathrm{DI}$ in the initial molar ratio from 1:2 to 1:3. Further increasing of $\mathrm{H}_{12}$ DI leads to decreasing of such parameters due to a higher crosslinking density and the formation of closed pores in PUU. The surface area and total pore volume were decreased from 68 to $28 \mathrm{~m}^{2} / \mathrm{g}$ and from 0.37 to $0.08 \mathrm{ml} / \mathrm{g}$, respectively (Table 1 ), but the size of PUU microparticles was increased from 1 to $30 \mu \mathrm{m}$. It could be proposed that the initial molar ratio $[\mathrm{PVA}]:\left[\mathrm{H}_{12} \mathrm{DI}\right]=1: 6$ at these conditions is limiting because of further increasing of the amount of $\mathrm{H}_{12}$ DI resulted in the formation of a clearly solid gel instead of microparticles.

Table 1. Properties of synthesized PUU microparticles $\left(t=90 \mathrm{~min}, T=90^{\circ} \mathrm{C}\right)$

\begin{tabular}{c|c|c|c|c|c}
\hline [PVA]:[H12DI] & Yield of PUU, $\%$ & $\begin{array}{c}\text { Quantity of NCO } \\
\text { groups, } \%\end{array}$ & Surface area, $\mathbf{~ m}^{2} / \mathbf{g}$ & $\begin{array}{c}\text { Total pore volume, } \\
\mathbf{m L} / \mathbf{g}\end{array}$ & Particle size, $\boldsymbol{\mu m}$ \\
\hline $1: 2$ & $38 \pm 2$ & $0.2 \pm 0.01$ & $38 \pm 2$ & $0.22 \pm 0.011$ & $1-2$ \\
\hline $1: 3$ & $50 \pm 2.5$ & $0.7 \pm 0.04$ & $68 \pm 3.8$ & $0.37 \pm 0.031$ & $2-5$ \\
\hline $1: 4$ & $54 \pm 2.7$ & $0.5 \pm 0.03$ & $67 \pm 3.4$ & $0.24 \pm 0.018$ & $4-9$ \\
\hline $1: 5$ & $55 \pm 2.4$ & $0.3 \pm 0.02$ & $54 \pm 2.4$ & $0.08 \pm 0.004$ & $5-12$ \\
\hline $1: 6$ & $55 \pm 2.1$ & $0.2 \pm 0.01$ & $28 \pm 1.6$ & $0.08 \pm 0.006$ & $10-30$ \\
\hline
\end{tabular}
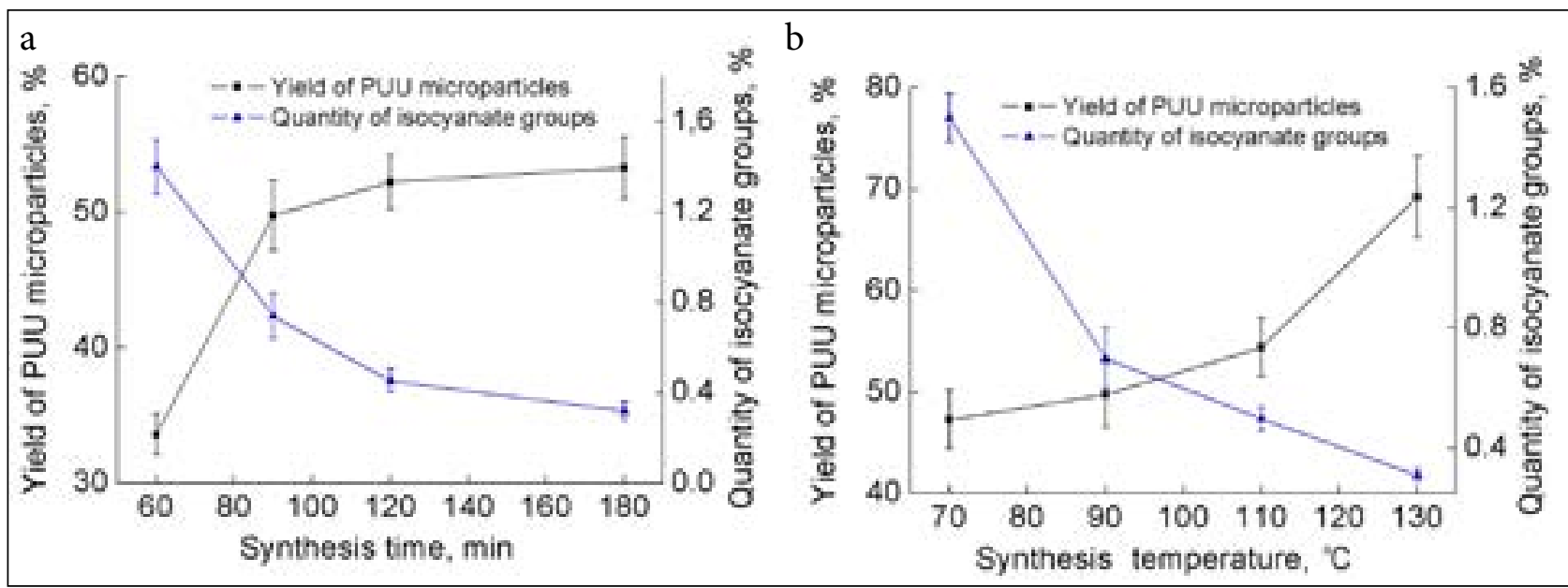

Fig. 1. The yield of PUU microparticles and the quantity of isocyanate groups as a function of synthesis time $\left(T=90^{\circ} \mathrm{C}\right)(\mathrm{a})$ and synthesis temperature $(t=90 \mathrm{~min})(\mathrm{b})\left([\mathrm{PVA}]:\left[\mathrm{H}_{12} \mathrm{Dl}\right]=1: 3\right)$ 


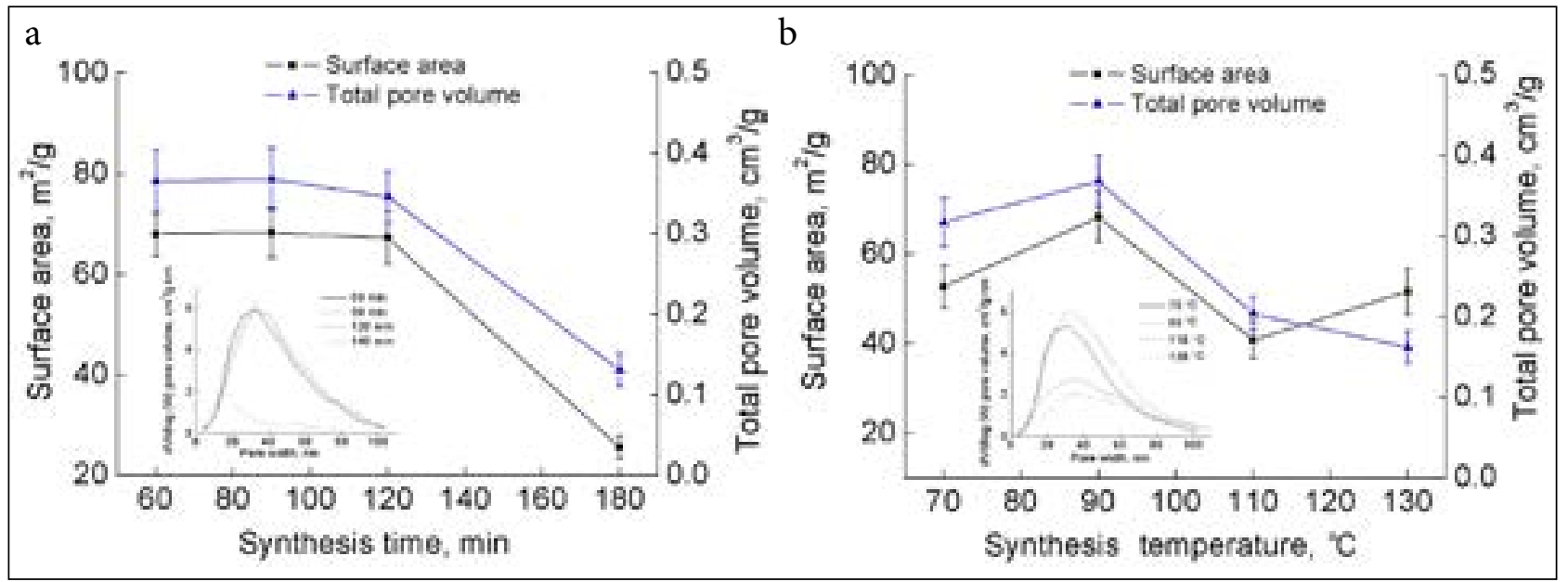

Fig. 2. The surface area and total pore volume of PUU microparticles as a function of synthesis time $\left(T=90^{\circ} \mathrm{C}\right)(\mathrm{a})$ and synthesis temperature $(t=90 \mathrm{~min})(\mathrm{B})\left([\mathrm{PVA}]:\left[\mathrm{H}_{12} \mathrm{DI}\right]=1: 3\right)$. The inner panes indicate the pore size distribution of PUU microparticles as a function of synthesis time and temperature

We could make a prediction that increasing the amount of diisocyanate resulted in a more extensive reaction between isocyanate and water which accelerates the crosslinking and amount of hooked $\mathrm{CO}_{2}$ bubbles in the PUU microparticles and decreasing the surface area and the total pore volume of the carrier. The pore width of PUU microparticles has a wide distribution with a dominant maximum at $32 \mathrm{~nm}$ in all cases with exception of carrier which was obtained when the molar ratio of PVA and $\mathrm{H}_{12}$ DI was 1:6. In the last case, the pore width distribution has a very wide profile without the dominant pore width.

The time and temperature of the synthesis have a significant impact on the quantity of isocyanate groups and the yield of PUU microparticles. When the synthesis time was prolonged from 60 to $180 \mathrm{~min}$ (Fig. 17), the quantity of the isocyanate groups decreased from 1.4 to $0.32 \%$, and the yield increased from 33 to $53 \%$. The same effects occurred when the synthesis temperature was changed from 70 to $130^{\circ} \mathrm{C}$ : the quantity of isocyanate groups decreased from 1.5 to $0.31 \%$ and the yield increased from 47 to $69 \%$ (Fig. 1 b). Also, under these synthesis conditions, the surface area $\left(68-25 \mathrm{~m}^{2} / \mathrm{g}\right)$ and the total pore volume $(0.365-0.131 \mathrm{ml} / \mathrm{g})$ were shifted to lower values (Fig. 2a, b). When the synthesis time was prolonged to $180 \mathrm{~min}$, the crosslinking reactions were dominant and as a consequence the decreased surface area and total pore volume were obtained. The dominant pore width shifted from 32 to $14 \mathrm{~nm}$ in this case (Fig. 2a). It was observed that at $110^{\circ} \mathrm{C}$ the crosslinking reactions were dominant. At the same time, the rate of reactions between the water molecules and the isocyanate groups also increased. Under these conditions, the formed $\mathrm{CO}_{2}$ bubbles were entrapped into the PUU matrix and closed pores were formed, and therefore the reduced surface area and total pore volume were obtained. The pore width distribution with a dominant maximum at $38 \mathrm{~nm}$ was observed (Fig. 2b). Increasing the synthesis temperature to $130^{\circ} \mathrm{C}$ resulted in the formation of soft PUU gel. After the liophylization of PUU gel, the surface area $\left(52 \mathrm{~m}^{2} / \mathrm{g}\right)$ and total pore volume $(0.162 \mathrm{ml} / \mathrm{g})$ were estimated (Fig. 2b).

\section{Assay of BsMa immobilization onto porous PUU microparticles}

PUU synthesis parameters, such as the initial molar ratio, time and temperature, have a significant effect on the efficiency of BsMa immobilization (EI) on the PUU carrier. In particular, the initial molar ratio of PVA to $\mathrm{H}_{12}$ DI showed an effect on EI and on the yield of immobilization by protein (YP) of BsMa (Table 2). The immobilization of BsMa onto the porous PUU microparticles could be carried out by covalent attachment and physical adsorption. The covalent immobilization of the enzyme onto the carrier could proceed via reactions of free isocyanate groups of PUU microparticles with amino or hydroxyl groups of enzyme and urethane or urea linkage could be formed. The immobilization of enzyme by physical adsorption depends on 
the porosity properties of PUU microparticles such as the surface area, pore volume and pore size distribution. According to the literature [33], the enzyme can easily get into the pores whose diameters are in a range of $30-100 \mathrm{~nm}$. Porous PUU microparticles have a proper surface area, pore volume and formed pores, whose dominant width $(32 \mathrm{~nm})$ is enough for the immobilization of BsMa. The hydrodynamic diameter of BsMa in the sodium citrate buffer $(0.1 \mathrm{M}, \mathrm{pH}=5.0)$ is $4 \mathrm{~nm}$ (it was measured using a dynamic light scattering instrument (Perkin Elmer) when $380 \mathrm{U}$ of BsMa were dissolved in $5 \mathrm{ml}$ of buffer. Therefore, BsMa could easily enter into the pores and attach by covalent linking or physical adsorption without any diffusion limit and steric hindrance. EI of BsMa onto the PUU microparticles increased from 60 to $88 \%$ and the yield of immobilization by protein (YP) increased from 63 to $90 \%$ when the initial molar ratio of PVA and $\mathrm{H}_{12} \mathrm{DI}$ was changed from 1:2 to $1: 3$. The further increase of $\mathrm{H}_{12} \mathrm{DI}$ in the PUU synthesis led to the decrease in the EI and YP of BsMa. This is due to the fact based on the results of the synthesis of PUU microparticles (Table 1), because the quantity of isocyanate groups, the surface area and the total pore volume decreased, and the possibilities of the immobilization of enzyme also decreased. The enzyme could be immobilized mainly due to physical adsorption but not covalent attachment in such cases.

Table 2. The efficiency and yield of the immobilization and storage stability of BsMa immobilized onto the PUU microparticles $\left(t=90 \mathrm{~min}, T=90^{\circ} \mathrm{C}\right)$

\begin{tabular}{c|c|c|cc}
\hline \multirow{2}{*}{ [PVA]:[H12DI] } & \multirow{2}{*}{ El, \% } & \multirow{2}{*}{ YP, \% } & \multicolumn{2}{|c}{ Residual activity, \% } \\
\cline { 4 - 5 } & & & $\mathbf{1 4}$ days & $\mathbf{2 8 ~ d a y s ~}$ \\
\hline Native BsMa & $100 \pm 4$ & - & $70 \pm 4$ & $56 \pm 3$ \\
\hline $1: 2$ & $60 \pm 3$ & $63 \pm 3$ & $96 \pm 5$ & $66 \pm 3$ \\
\hline $1: 3$ & $88 \pm 4$ & $90 \pm 5$ & $86 \pm 3$ & $72 \pm 4$ \\
\hline $1: 4$ & $68 \pm 3$ & $71 \pm 4$ & $83 \pm 4$ & $64 \pm 3$ \\
\hline $1: 5$ & $51 \pm 3$ & $53 \pm 3$ & $81 \pm 4$ & $60 \pm 2$ \\
\hline $1: 6$ & $49 \pm 2$ & $51 \pm 3$ & $21 \pm 2$ & $5 \pm 1$ \\
\hline
\end{tabular}

The EI of BsMa onto the carrier also depends on the PUU synthesis time (Fig. 3a) and temperature (Fig. $3 \mathrm{~b}$ ). Increasing the synthesis time of PUU microparticles from $60 \mathrm{~min}$ to $180 \mathrm{~min}$ ( $\left.[\mathrm{PVA}]:\left[\mathrm{H}_{12} \mathrm{DI}\right]=1: 3, \mathrm{~T}=90^{\circ} \mathrm{C}\right)$ resulted in decreasing the EI of BsMa from $91 \%$ to $59 \%$ (Fig. 3 a) because at these conditions the quantity of isocy-

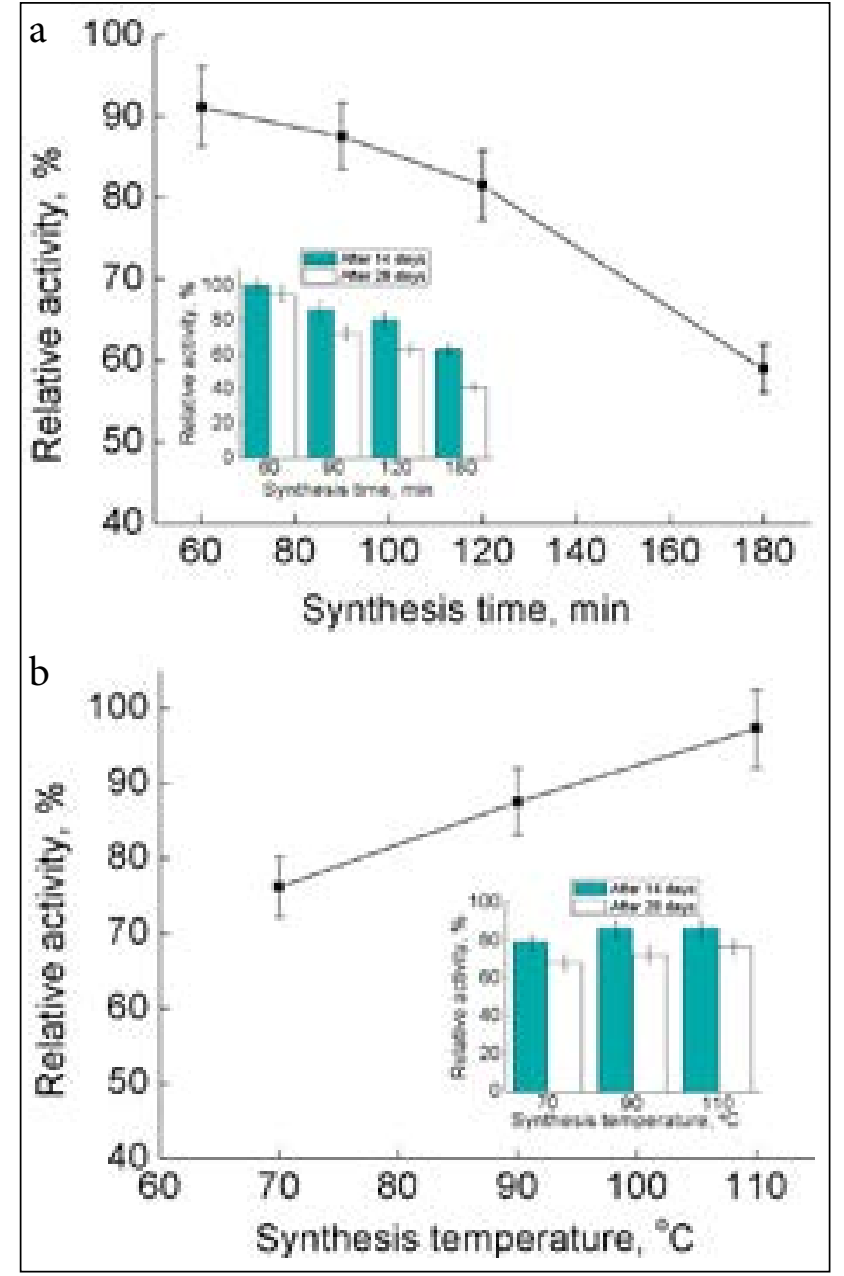

Fig. 3. El of BsMa onto the microparticles as a function of PUU synthesis time $\left(T=90^{\circ} \mathrm{C}\right)$ (a) and temperature ( $t=90 \mathrm{~min}$ ) (b) ([PVA]:[HMDI] = 1:3). The inner panes indicate the storage stability of the immobilized BsMa onto the PUU microparticles after 14 and 28 days of storage (in $0.1 \mathrm{M}$ citrate buffer, $\mathrm{pH}=5.0, T=4^{\circ} \mathrm{C}$ )

anate groups (Fig. 1a), the surface area and the total pore volume (Fig. 2a) were decreased. Consequently, in a short time of the synthesis of the PUU microparticles, a higher quantity of the isocyanate groups was obtained and BsMa can be immobilized by covalent attachment. Also, under these conditions, a higher surface area and total pore volume of PUU were obtained and this can lead to increasing EI of the enzyme on the carrier via adsoption. When the PUU synthesis time was prolonged to $180 \mathrm{~min}$, the immobilization of BsMa proceeded mainly by physical adsorption and the EI of the enzyme was decreased, because the quantity of isocyanate groups, values of the surface area, the total pore volume and pore width were low.

Unexpected results were obtained when BsMa was immobilized on the PUU microparticles 
synthesized at temperatures from 70 to $110^{\circ} \mathrm{C}$ ( $[\mathrm{PVA}]:\left[\mathrm{H}_{12} \mathrm{DI}\right]=1: 3, t=90 \mathrm{~min}$ ) (Fig. $3 \mathrm{~b}$ ). The immobilization prediction is the opposite compared with the immobilization results. EI of BsMa onto the PUU microparticles increased from 76 to $97 \%$ when the quantity of isocyanate groups decreased from 1.5 to $0.3 \%$ (Fig. $1 \mathrm{~b}$ ). According to the previous data of this article, the EI of BsMa onto the PUU microparticles showed a correlation with the porosity and quantity of isocyanate groups of the carrier. The highest EI of BsMa was obtained when the highest surface area, total pore volume and quantity of isocyanate groups were on the PUU microparticles. However, the highest EI of BsMa onto the porous PUU microparticles was obtained when the synthesis temperature was $110^{\circ} \mathrm{C}$ despite the fact that at these conditions the quantity of isocyanate groups was equal to $0.5 \%$, the surface area was only $41 \mathrm{~m}^{2} / \mathrm{g}$ and the total pore volume was $0.204 \mathrm{ml} / \mathrm{g}$. Therefore, we could do a prediction that in this case the width and depth of pores are perfectly suitable for enzyme immobilization and it could proceed by covalent attachment and physical adsorption. A soft PUU gel was formed instead of microparticles and the immobilization of BsMa was unsuccessful when the synthesis of PUU was carried out at $130^{\circ} \mathrm{C}$.

The change in the value of $\mathrm{K}_{\mathrm{M}}$ was observed for the enzyme immobilized onto the porous $\mathrm{PUU}$ microparticles ([PVA]:[H $\left.{ }_{12} \mathrm{DI}\right]=1: 3, T=90^{\circ} \mathrm{C}$, $t=90 \mathrm{~min}$ ) to compare with the native enzyme. Using starch as a substrate, a value of $2.9 \%$ was obtained in the case of maltogenic $\alpha$-amylase immobilized on the PUU microparticles in comparison to $1.8 \%$ for the native enzyme. The change in $K_{M}$ after the immobilization shows that the immobilized enzyme is less affinitive to a starch solution as a substrate than a native enzyme. The value of the maximum reaction rates of starch hydrolysis $\left(V_{\max }\right)$ increased after the immobilization from $4.7 \cdot 10^{-4} \mathrm{~mol} /(\mathrm{min} \cdot \mathrm{L})$ for the soluble enzyme to $6.3 \cdot 10^{-4} \mathrm{~mol} /(\mathrm{min} \cdot \mathrm{L})$ for the enzyme immobilized on the PUU microparticles.

\section{Investigation of storage stability and reusability of immobilized BsMa}

Enzymes are very sensitive biocatalysts against environmental conditions and may lose their activities quite easily [34]. Thus, to characterize storage stability of an enzyme for preparative or industrial uses is meaningful. Data of the storage stability of immobilized BsMa could show the covalent fixation of the enzyme onto the PUU microparticles or the nonspecific adsorption, which is mainly based on physical adsorption and ionic binding [35-38].

The storage stability of the immobilized and native BsMa was measured by its residual activity after 14 and 28 days of storage in the sodium citrate buffer $(0.1 \mathrm{M}, \mathrm{pH} 5.0)$ at $4^{\circ} \mathrm{C}$ (Table 2, Fig. 3). The residual activities of the native BsMa were 70 and $56 \%$ after the storage in the buffer for 14 and 28 days, respectively. Under the same conditions, the residual activities of the immobilized BsMa onto the PUU microparticles synthesized from PVA and $\mathrm{H}_{12} \mathrm{DI}$ when the initial molar ratios were from $1: 2$ to $1: 5\left(t=90 \mathrm{~min}, T=90^{\circ} \mathrm{C}\right)$ were higher than that of of native enzyme.

The storage stability of the immobilized BsMa on the PUU carrier depends not only on the molar ratio of PVA and $\mathrm{H}_{12} \mathrm{DI}$, but also on the time and temperature of the synthesis. When the synthesis time was prolonged from 60 to $180 \mathrm{~min}$ ([PVA]: $\left[\mathrm{H}_{12} \mathrm{DI}\right]=1: 3, T=90^{\circ} \mathrm{C}$ ), the residual stability of the immobilized BsMa after 28 days of storage decreased from 95 to $41 \%$ (Fig. 3a). In our previous work [30], it was predicted that the storage stability of the immobilized enzyme depends on the quantity of isocyanate groups onto the PUU microparticles. The storage stability of the immobilized BsMa onto the porous PUU microparticles was high and in such way it was confirmed that the enzyme was immobilized by covalent attachment when the synthesis time of the carrier was $60 \mathrm{~min}$. The major part of enzyme activity after 28 days of storage was lost when BsMa was immobilized onto the carrier whose synthesis time was $180 \mathrm{~min}$. It was confirmed that the immobilization of the enzyme onto the carrier mainly proceeds by physical adsorption in this case.

On the other hand, the storage stability of the immobilized BsMa should decrease with increasing the synthesis temperature of PUU because the quantity of isocyanate groups was depleted when the synthesis temperature was increased to $110^{\circ} \mathrm{C}$ and the values of the surface area and the mean pore volume were also decreased to lower values. However, the residual activity after 28 days of the storage of the immobilized BsMa was increased from 68 to $76 \%$ when the synthesis temperature of the carrier was increased from 70 to 
$110^{\circ} \mathrm{C}$ (Fig. $3 \mathrm{~b}$ ). It was confirmed that the synthesized PUU microparticles at $110^{\circ} \mathrm{C}$ temperature are suitable for BsMa immobilization.

Reusability of the immobilized enzyme is a very important approach to reduce the enzyme price and it is very simple to separate the immobilized enzyme from the product to stop the reaction. On the other hand, the reusability could show in which way the enzyme was immobilized onto the PUU microparticles. The immobilized BsMa was examined for the repeated catalysis in the batch operation immediately after its immobilization onto the PUU microparticles ([PVA]: $\left[\mathrm{H}_{12} \mathrm{DI}\right]=1: 3, t=90 \mathrm{~min}$, $T=90^{\circ} \mathrm{C}$ ). The residual activity of the immobilized enzyme onto the carrier was shifted to lower values after the first cycle and after 7 cycles it was equal to $62 \%$. The investigation confirmed that part of the enzyme was immobilized by physical adsorption.

\section{Effect of $\mathrm{NaCl}$ concentration on the enzymatic activity of native and immobilized BsMa}

Similar data of leaching of the enzyme from the immobilized carrier to the aqueous media can show whether the enzyme was immobilized via hydrophobic and Van der Walls interactions, hydrogen or ionic bonds and a high salt concentration can lead to ion exchange and washing out of the immobilized enzyme [33, 38]. The relative activity of the native BsMa was increased by $10 \%$ when the concentration of $\mathrm{NaCl}$ was increased from 0 until $0.02 \mathrm{M}$, further increasing the salt concentration to $0.1 \mathrm{M}$ resulted in the decreased activity of the native enzyme by $10 \%$ in comparison with the obtained activity in the buffer solution. An additional addition of $\mathrm{NaCl}$ to the buffer containing the immobilized BsMa may induce the desorption of physically bounded enzyme from the carrier. Therefore, to verify this, the activity of the immobilized BsMa was evaluated in accordance with the Section 'Effect of temperature on the enzymatic activity of native and immobilized BsMa'. The activity of immobilized BsMa on the carrier depends on the concentration of $\mathrm{NaCl}$, and it fell down when the concentration of $\mathrm{NaCl}$ increased from 0 to $0.1 \mathrm{M}$. When the $\mathrm{NaCl}$ concentration was $0.02 \mathrm{M}$, the relative activity of the immobilized enzyme onto the carrier was decreased until $82 \%$. It could be proposed that in this case the enzyme which was immobilized via the hydrophobic and Van der Walls interactions and partially hydrogen bonds was desorbed. Further increasing the salt concentration to $0.1 \mathrm{M}$ resulted in decreasing the relative activity to $67 \%$. At this point, the enzyme which was immobilized via the hydrogen and ionic bonds may leach. These results have a good correlation with the storage stability and reusability results which were described in the Section 'Investigation of storage stability and reusability of immobilized BsMa'. We could propose that the major part of the immobilized enzyme was attached by covalent fixation and a sufficient quantity of isocyanate groups onto the PUU microparticles is $0.7 \%$. Also, the same prediction is appropriate for the immobilization of enzyme onto the porous PUU microparticles which were obtained when the synthesis temperature was $110^{\circ} \mathrm{C}\left([\mathrm{PVA}]:\left[\mathrm{H}_{12} \mathrm{DI}\right]=1: 3, t=90 \mathrm{~min}\right)$. The values of the surface area and pore volume also have an impact on the EI of the enzyme.

\section{Effect of temperature on the activity of native and immobilized BsMa}

The influence of temperature on the activity of native and immobilized enzyme onto the PUU microparticles $\left([\mathrm{PVA}]:\left[\mathrm{H}_{12} \mathrm{DI}\right]=1: 3, t=90 \mathrm{~min}, T=90^{\circ} \mathrm{C}\right)$ was examined (Fig. A). The highest activity of native BsMa was obtained when hydrolysis of the starch was performed in a buffer solution at $60^{\circ} \mathrm{C}$. The relative activity of the immobilized BsMa was higher at high temperatures than the native enzyme.

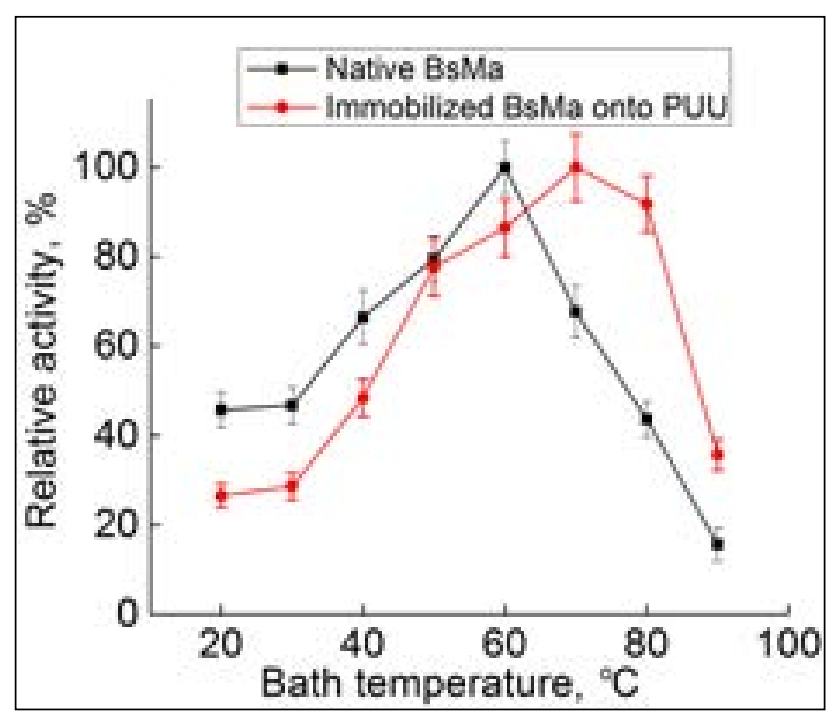

Fig. 4. The relative activity of the native and immobilized BsMa onto the PUU microparticles as a function of bath temperature ([PVA]:[H $\left.{ }_{12} \mathrm{DI}\right]=1: 3, t=90 \mathrm{~min}, T=90^{\circ} \mathrm{C}$ ) 
The relative activity at $70^{\circ} \mathrm{C}$ was equated to $100 \%$. At $80^{\circ} \mathrm{C}$, the relative activity of the immobilized enzyme was $92 \%$. It decreased only at $90^{\circ} \mathrm{C}$, but its value was still higher compared to that of the native BsMa. The immobilized BsMa onto the porous PUU microparticles which were synthesized from PVA and $\mathrm{H}_{12} \mathrm{DI}$ has shown $20^{\circ} \mathrm{C}$ higher optimal temperature compared with that of the native BsMa.

\section{CONCLUSIONS}

Novel porous PUU microparticles from PVA and $\mathrm{H}_{12}$ DI were synthesized and used for the immobilization of BsMa. EI of BsMa depends on the porosity as well as the quantity of isocyanate groups of the carrier. These parameters can be varied by changing the initial synthesis parameters of PUU microparticles, such as the initial molar ratio, time and temperature. The best result of the EI of BsMa onto the porous PUU (97\%) was obtained when the initial molar ratio of PVA to $\mathrm{H}_{12}$ DI was $1: 3$, $t=90 \mathrm{~min}$ and $T=110^{\circ} \mathrm{C}$. A high storage stability of the immobilized BsMa was observed after 28 days of storage. The reusability of immobilized BsMa and the effect of salt $(\mathrm{NaCl})$ showed that the enzyme was immobilized by covalent attachment and physical adsorption. The highest activity of the immobilized BsMa onto the carrier was achieved when temperature was $80^{\circ} \mathrm{C}$ and it was $20^{\circ} \mathrm{C}$ higher compared with that of the native enzyme. The synthesized PUU microparticles which were used for the immobilization of BsMa have a potential for application in the production of a high maltose syrup in the food industry. The potential for the immobilization of other enzymes onto the PUU microparticles for biotechnological purposes is also very promising.

Received 7 May 2021 Accepted 21 May 2021

\section{References}

1. B. Krajewska, Enzyme Microb. Technol., 36, 126 (2004).

2. J. Mehta, N. Bhardwaj, S. K. Bhardwaj, Coord. Chem. Rev., 322, 30 (2016).

3. N. Miletić, A. Nastasović, K. Loos, Bioresour. Technol., 115, 126 (2012).

4. R. A. Sheldon, Adv. Synth. Catal., 349, 1289 (2007).

5. W. Na, Q. Wei, Z. C. Zou, Q. Y. Li, Z. R. Nie, Mater Lett., 62, 3707 (2008).
6. S. Gao, Y. Wang, T. Wang, G. Luo, Y. Dai, Bioresour. Technol., 100, 996 (2009).

7. P. He, G. Greenway, S. J. Haswell, Process Biochem., 45, 593 (2010).

8. C. Bernal, L. Sierra, M. Mesa, Chem. Cat. Chem., 3, 1948 (2011).

9. G. Songulashvili, G. A. Jimenéz-Tobón, C. Jaspers, M. J. Penninckx, Fungal Biol., 116, 883 (2012).

10. C. Wang, Y. Li, G. Zhou, X. Jiang, Y. Xu, Z. Bu, Mater. Sci. Eng., C, 45, 261 (2014).

11. E. Biró, D. Budugan, A. Todea, F. Péter, S. Klébert, T. Feczkó, J. Mol. Catal. B Enzym., 123, 81 (2016).

12. S. Gopinath, S. Sugunan, Appl. Clay Sci., 35, 67 (2007).

13. U. H. Zaidan, M. B. A. Rahman, M. Basri, S. S. Othman, R. N. Z. R. A. Rahman, A. B. Salleh, Appl. Clay Sci., 47, 276 (2010).

14. S. Mitchell, J. Pérez-Ramírez, Catal. Today, 168, 28 (2011).

15. K. M. de Lathouder, D. Lozano-Castelló, A. LinaresSolano, S. A. Wallin, F. Kapteijn, J. A. Moulijn, Microporous Mesoporous Mater., 99, 216 (2007).

16. A. V. P. Albertini, Cadena PG, Silva JL, et al., Chem. Eng. J., 187, 341 (2012).

17. N. Miletić, Z. Vuković, A. Nastasović, K. Loos, J. Mol. Catal. B Enzym., 56, 196 (2009).

18. M. Rana, A. Kumari, G. S. Chauhan, K. Chauhan, Int. J. Biol. Macromol., 66, 46 (2014).

19. F. A. P. Lage, J. J. Bassi, M. C. C. Corradini, L. M. Todero, J. H. H. Luiz, A. A. Mendes, Enzyme Microb. Technol., 84, 56 (2016).

20. S. Phadtare, A. Kumar, V. P. Vinod, et al., Chem. Mater., 15, 1944 (2003).

21. S. Phadtare, S. Vyas, D. V. Palaskar, et al., Biotechnol. Prog., 20, 1840 (2004).

22. V. Chiaradia, A. Valério, D. de Oliveira, P. H. H. Araújo, C. Sayer, J. Mol. Catal. B Enzym., 131, 31 (2016).

23. X. Wang, E. Ruckenstein, Biotechnol. Prog., 9, 661 (1993).

24. K. P. Dhake, A. H. Karoyo, M. H. Mohamed, L. D. Wilson, B. M. Bhanage, J. Mol. Catal. B Enzym., 87, 105 (2013).

25. E. P. Cipolatti, A. Valério, G. Nicoletti, et al., J. Mol. Catal. B Enzym., 109, 116 (2014).

26. S. Budriene, T. Romaskevic, K. Pielichowski, J. Pielichowski, Polym. Adv. Technol., 18, 67 (2007).

27. T. Romaskevic, E. Viskantiene, S. Budriene, A. Ramanaviciene, G. Dienys, J. Mol. Catal. B Enzym., 64, 172 (2010).

28. A. Strakšys, T. Kochanè, S. Budrienè, Chemija., 24, 160 (2013).

29. A. Straksys, T. Kochane, S. Budriene, Food Chem., 211, 294 (2016).

30. R. Makuska, Synthesis and Characterization of Polymers, VU leidykla, Vilnius (2006). In Lithuanian. 
31. J. S. Lv, X. Y. Liu, J.-X. Xu, et al., Ind. Crops Prod., 50, 787 (2013).

32. P. K. Smith, R. I. Krohn, G. T. Hermanson, et al., Anal. Biochem., 150, 76 (1985).

33. L. Cao, Carrier-bound Immobilized Enzymes, Willey-VCH, Weinheim (2005).

34. O. Turunc, M. V. Kahraman, Z. S. Akdemir, N. Kayaman-Apohan, A. Güngör, Food Chem., 112, 992 (2009).

35. R. A. Sheldon, Adv. Synth. Catal., 349, 1289 (2007).

36. A. Amine, H. Mohammadi, I. Bourais, G. Palleschi, Biosens. Bioelectron., 21, 1405 (2006).

37. H. J. Cha, H. G. Yoon, Y. W. Kim, et al., Eur. J. Biochem., 253, 251 (1998).

38. U. Hanefeld, L. Gardossi, E. Magner, Chem. Soc. Rev., 38, 453 (2009).
Antanas Strakšys, Tatjana Kochanė, Sandra Mačiulytė, Saulutė Budrienè

\section{AKYTOS POLIURETANKARBAMIDINĖS MIKROKAPSULĖS MALTOGENINEI a-AMILAZEI IŠ BACILLUS STEAROTHERMOPHILUS IMOBILIZUOTI}

Santrauka

Bacillus stearothermophilus maltogeninè $a$-amilazè buvo imobilizuota ant poringu poliuretankarbamidinių (PUU) mikrodalelių, gautų iš polivinilo alkoholio ir 4,4'-metileno cikloheksildiizocianato. Ištirta PUU sintezès parametrų, tokių kaip pradinių komponentų molinis santykis, sintezès trukmè ir temperatūra, ittaka poringumui, paviršiaus plotui, mikrodalelių struktūrai ir imobilizuoto fermento kataliziniam aktyvumui bei stabilumui. Didžiausias fermento imobilizavimo ant PUU nešiklio efektyvumas yra $97 \%$, o didžiausias imobilizuoto fermento stabilumas siekia $95 \%$ po 28 dienu laikymo $4{ }^{\circ} \mathrm{C}$ temperatūroje. Maltogeninès $\alpha$-amilazès imobilizavimas padidina fermento temperatūrinị optimumą: imobilizuotos maltogeninès $\alpha$-amilazès jis siekia $80^{\circ} \mathrm{C}$ ir yra $20^{\circ} \mathrm{C}$ aukštesnis nei natūralaus fermento. Ištyrus joninès jègos ịtaką imobilizuoto fermento aktyvumui nustatyta, kad fermentas imobilizuojasi kovalentiniu būdu, tačiau dalis fermento prijungta fizikinès adsorbcijos būdu. Imobilizuota maltogeninè $\alpha$-amilazè atlaiko mažiausiai 7 panaudojimo ciklus vykdant fermentinę reakciją periodiniame vonios tipo reaktoriuje. Imobilizuoti maltogeninès $\alpha$-amilazès preparatai galètų būti sèkmingai taikomi biotechnologijoje gaminant didelị maltozès kiekị turinčius sirupus. 